\title{
Nutrient and energy composition of flesh, limbs and carapace of Callinectes amnicola (Blue Crab) from Great Kwa river, South East Nigeria
}

\author{
Williams $1 \mathrm{O}^{1}$, Ekpenyong $\mathrm{E}^{2}$, Lawal $\mathrm{OO}^{1}$, Essien $\mathrm{NC}^{3}$ and Edemumoh $\mathrm{TO}^{2}$ \\ ${ }^{1}$ Human Nutrition and Dietetics Unit, Department of Biochemistry, University of Calabar, Nigeria \\ ${ }^{2}$ Department of Zoology and Environmental Biology, University of Calabar, Nigeria \\ ${ }^{3}$ Department of Nursing Science, University of Calabar, Nigeria. \\ Corresponding Author Email: imawills@yahoo.com Tel: 234-80-35018175.
}

ABSTRACT

\begin{abstract}
This study compared some nutrient and energy levels in three body parts of Callinectes amnicola using AOAC methods. Fresh crab specimens were collected from Great Kwa River landing site in CalabarNigeria. Results showed that $C$. amnicola is rich in nutrients, which were unevenly distributed across the body parts. For proximate, moisture was the most predominant $(71.50 \pm 0.10 \mathrm{~g} / 100 \mathrm{~g}$ $81.40 \pm 0.01 \mathrm{~g} / 100 \mathrm{~g}$ ), the dry matter representing about one-fourth the total body weight. Protein and fat recorded highest values in the flesh $(36.30 \pm 0.01 \mathrm{~g} / 100 \mathrm{~g}$ and $24.54 \pm 0.02 \mathrm{~g} / 100 \mathrm{~g}$, respectively) and least in the carapace $(30.30 \pm 0.02 \mathrm{~g} / 100 \mathrm{~g}$ and $12.59 \pm 0.01 \mathrm{~g} / 100 \mathrm{~g}$, respectively) $(p<0.05)$. On the contrary, the flesh had the lowest carbohydrate $(29.82 \pm 0.02 \mathrm{~g} / 100 \mathrm{~g})$, ash $(7.26 \pm 0.02 \mathrm{~g} / 100 \mathrm{~g})$ and fibre $(1.91 \pm 0.01 \mathrm{~g} / 100 \mathrm{~g})$ contents, which showed highest values in the carapace $(40.10 \pm 0.10 \mathrm{~g} / 100 \mathrm{~g}, 13.17 \pm 0.02 \mathrm{~g} / 100 \mathrm{~g}$ and $3.70 \pm 0.10 \mathrm{~g} / 100 \mathrm{~g}$, respectively). Energy value was generally low $(4.50 \pm 0.09 \mathrm{kcal} / \mathrm{g}-5.79 \pm 0.36 \mathrm{kcal} / \mathrm{g})$. For minerals, sodium $(139.25 \pm 0.36 \mathrm{mg} / 100 \mathrm{~g}-154.46 \pm 0.08 \mathrm{mg} / 100 \mathrm{~g})$ and calcium $(105.46 \pm 0.01 \mathrm{mg} / 100 \mathrm{~g}$ $143.53 \pm 0.06 \mathrm{mg} / 100 \mathrm{~g}$ ) were the most predominant. The micro-mineral elements iron and zinc also occurred in appreciable quantities, with the highest contents in the flesh $(16.42 \pm 0.10 \mathrm{mg} / 100 \mathrm{~g}$ and $4.47 \pm 0.06 \mathrm{mg} / 100 \mathrm{~g}$, respectively) and lowest in the carapace $(9.56 \pm 0.06 \mathrm{mg} / 100 \mathrm{~g}$ and $2.53 \pm 0.12 \mathrm{mg} / 100 \mathrm{~g}$, respectively). The flesh, limbs and carapace of $C$. amnicola are a significant source of nutrients. Toxicological and biological investigation should consider possible use of powdered nutritious exoskeleton of $C$. amnicola as nutraceutical agent.
\end{abstract}

Keywords: Crab, proximate composition, energy, mineral, nutraceutical.

\section{INTRODUCTION}

Globally, the demand and consumption of aquatic foods has increased rapidly due primarily to their acclaimed health promoting characteristics. Fish and shellfish are the two principal groups of aquatic resources used in the human diet. They are among the few foods that still come mostly from the wild. Shellfish are hard body aquatic organisms such as crabs, prawns, shrimps, lobsters, mussels and oysters. Crabs belong to the group of shellfish called crustaceans, identified by their hard shells and ten appendages or legs: hence, they are decapods. It has been reported that crabs and other crustaceans account for about one-fifth or $20 \mathrm{~g} / 100 \mathrm{~g}$ of all the foods obtained from the seas, rivers, lakes, and other aquatic sources (Udo and Arazu, 2012). Also, crabs alone make up about $20 \mathrm{~g} / 100 \mathrm{~g}$ of all marine crustaceans consumed worldwide (Elegbede and Fashina-Bombata, 2013). Over 100 species of crab are known worldwide with blue crabs being the most commonly consumed (Omotayo et al., 2013). Crab is used in a wide variety of dishes including salads, soups, pates, starters, or served as a main course. The taste, texture and nutritional benefits of crab meat make it a versatile delicacy all over the world.

The crab meat is nutritionally valuable as a rich source of high quality protein, minerals and vitamins (Adeyeye, 2002; Skonberg and Perkins, 2002; Omotayo et al., 2013) with low levels of fat and carbohydrates (Udo and 
Arazu, 2012). A report of the Shellfish Association of Great Britain shows that the protein in shellfish is high in essential amino acids and is highly digestible because of the lack of connective tissue (SAGB, 2009). The minerals found in abundance in crab include calcium, copper, zinc, phosphorus and iron (Adeyeye, 2002), with less amounts of chromium and selenium. Crab is also a rich source of fat-soluble vitamins A, D and E (Dias et al., 2003) and a number of B vitamins (Holland et al., 1993). The lipids in crabs constitute a major source of highly unsaturated fatty acids especially the omega- 3 fatty acids eicosapentaenoic acid (EPA) and docosahexaenoic acid (DHA) (IOM, 2006).

A number of studies have linked the health benefits of crab meat to its high content of omega-3 fatty acids, which the crab obtains from phytoplanktons and algae in its natural habitat. Research has shown that omega-3 fatty acids help in the prevention and control of many non-communicable diseases including obesity, diabetes mellitus, cancer, arthritis, hypertension and heart disease (SAGB, 2009; Defilippis et al., 2010; Wilk et al., 2012). In fact, studies (Roth and Harris, 2010; Nodari et al., 2011) show that a diet rich in omega-3 fatty acids improves the ratio of high density lipoprotein (HDL) to low density lipoprotein (LDL) cholesterol, a ratio used by many heart specialists to predict the risk of heart disease. In recognition of their cardioprotective effect, the American Heart Association has recommended omega-3 fatty acids mainly from sea foods as part of the dietary approaches to prevent and treat hypertension (Appel et al., 2006).

Protein energy malnutrition is widespread in Nigeria (Ubesie and Ibeziakor, 2012) and micronutrient deficiency particularly those of vitamin A, iron, zinc and iodine are also common (Maziya-Dixon et al., 2004). This is coupled with emerging epidemics of diet-related noncommunicable diseases such as obesity, diabetes, cancer, hypertension, heart disease and atherosclerosis among Nigerians. Dietary deficiencies can be minimized by increased consumption of protein-rich foods especially from animal sources. However in Nigeria, conventional animal protein food sources such as cow, goat and chicken are inadequate and often beyond the economic reach of most households. Crab has become one of the chief sources of animal protein to the low- and highincome earners due to its low price, high market availability, and copious health benefits (Adeyeye, 1996).

Many crab species are consumed in various parts of the world including Nigeria. A number of studies have been carried out to document the nutrient composition of crabs but literature on the nutrient composition of crabs is still incomplete. Also, available reports suggest that the chemical composition of crabs varies greatly among species and from an individual crab to another, depending on age, sex, environment, and season (Petricorena, 2014).

Again, preparing crab for consumption includes the removal and discarding of the hard parts such as the carapace. Also during crab consumption, the remaining exoskeleton/hard parts not removed during food preparation are usually discarded by the consumer. This study was designed to compare the nutrient composition of the edible and non-edible (hard) parts of crab and to investigate the effect of continuous exclusion of the hard parts of crab from human diets. Hence, we determined and compared the proximate, energy and mineral composition of the flesh, limbs and carapace of the marine blue crab (Callinectes amnicola) obtained from the great Kwa River, South East Nigeria.

\section{MATERIALS AND METHODS}

\section{Sample collection}

Thirty (30) fresh matured lively specimens of Callinectes amnicola (marine blue crab) were purchased from fishermen at the landing site of the Great Kwa River in November 2014. This river is located between latitudes $40^{\circ} 45^{\prime}$ and $50^{\circ} 15^{\prime} \mathrm{N}$ and longitudes $80^{\circ} 15^{\prime}$ and $80^{\circ}$ $30^{\prime} \mathrm{E}$ with an estimated length of $56 \mathrm{~km}$ and width of $2.8 \mathrm{~km}$. The specimens were placed in an ice chest and immediately transported to the Research laboratory in the Department of Biochemistry, University of Calabar.

\section{Preparation for analyses}

The fresh crabs were washed in running tap water after which the different body parts: carapace, limbs and flesh were separately removed. Each group of body parts was dried in an electric oven at $105^{\circ} \mathrm{C}$ for 24 hours. The dried body parts were afterwards ground in an electric blender, packed in airtight plastic bottles and stored in the refrigerator at $4^{\circ} \mathrm{C}$ pending chemical analysis within 48 hours.

\section{Proximate analysis}

The proximate composition of the carapace, limbs and flesh was determined by the method of the Association of Official Analytical Chemists (AOAC, 2005). Moisture content was taken as the weight loss after drying $2 \mathrm{~g}$ of each fresh body part to a constant weight at $87-98^{\circ} \mathrm{C}$ with the aid of an electric oven (Astell Heason, England) for 24 hours. Crude protein was determined by the microKjeldahl method in which the total nitrogen in the sample was estimated and subsequently multiplied by a factor of 6.25. Fat content was obtained by acid hydrolysis and intermittent extraction with petroleum ether (B. P. 40$60^{\circ} \mathrm{C}$ ) using Soxhlet apparatus (Corning, England). Ash was determined by dry ashing or by measuring the residue left after incineration of a weighed portion of the sample at $600^{\circ} \mathrm{C}$ for 10 hours using a muffle furnace. 
Table 1. Proximate constituents in different body parts of Callinectes amnicola (g/100g dry matter)

\begin{tabular}{lllllll}
\hline & Moisture & Ash & Protein & Fat & Crude fibre & Carbohydrate \\
\hline Flesh & $81.40 \pm 0.06$ & $7.26 \pm 0.01$ & $36.30 \pm 0.06$ & $24.54 \pm 0.01$ & $1.91 \pm 0.01$ & $29.82 \pm 0.01$ \\
& & & & & & \\
Limbs & $79.50 \pm 0.06^{*}$ & $7.87 \pm 0.01^{*}$ & $34.63 \pm 0.03^{*}$ & $18.57 \pm 0.01^{*}$ & $2.81 \pm 0.01^{*}$ & $35.98 \pm 0.01^{*}$ \\
& & & & & & \\
Carapace & $71.43 \pm 0.03^{*, \mathrm{a}}$ & $13.17 \pm 0.01^{*, \mathrm{a}}$ & $30.30 \pm 0.02^{*, \mathrm{a}}$ & $12.63 \pm 0.04^{*, \mathrm{a}}$ & $3.70 \pm 0.01^{*, \mathrm{a}}$ & $40.10 \pm 0.06^{*, \mathrm{a}}$ \\
\hline
\end{tabular}

Values are expressed as mean \pm SEM, $n=3$.

* $=$ significantly different from flesh at $p<0.05$

$a=$ significantly different from limbs at $p<0.05$

Crude fibre was estimated by boiling the sample with $1.25 \%(\mathrm{w} / \mathrm{v})$ sulphuric acid and then with $1.25 \%(\mathrm{w} / \mathrm{v})$ sodium hydroxide and incinerating the residue at $550^{\circ} \mathrm{C}$; the loss in weight represented the crude fibre content of the sample (AOAC, 2005). Total carbohydrate content was obtained by difference after subtracting the moisture, protein, fat and ash from the total dry matter, expressed in percentage.

\section{Determination of energy value}

The caloric value, expressed as $\mathrm{kcal} / \mathrm{g}$ of each body part was calculated using the Atwater factors for protein, fat, and carbohydrate (Atwater \& Bryant, 1900). Accordingly, the amount of protein obtained by chemical analysis was multiplied by 4 , fat was multiplied by 9 , and digestible carbohydrate was multiplied by 4 . Energy was calculated as the sum of the three values. That is, Energy $=$ [protein $(x 4)+$ fat $(x 9)+$ carbohydrate $(x 4)] \mathrm{kcal} / \mathrm{g}$.

\section{Determination of mineral elements}

Elemental composition was analysed using the solution obtained by dry-ashing the samples at $550^{\circ} \mathrm{C}$ and dissolving in distilled water with a few drops of concentrated hydrochloric acid in a volumetric flask. Sodium $(\mathrm{Na})$ and potassium $(\mathrm{K})$ were measured with a Corning U.K. Model 405 flame photometer (AOAC, 2005) while iron ( $\mathrm{Fe})$, Zinc $(\mathrm{Zn})$, magnesium $(\mathrm{Mg})$ and calcium (Ca) were obtained spectrophotometrically (AOAC, 2005).

\section{Statistical analysis}

The results obtained were subjected to one-way analysis of variance (ANOVA) using the statistical package for social sciences (SPSS) 2009 (version 17.0). Statistical significance was accepted at $5 \%$ probability level.

\section{RESULTS}

\section{Proximate composition}

The proximate composition of the different body parts expressed as $\mathrm{g} / 100 \mathrm{~g}$ dry matter are presented in Table 1. The moisture content ranged from $71.50 \pm 0.10 \mathrm{~g} / 100 \mathrm{~g}$ in the carapace to $81.40 \pm 0.01 \mathrm{~g} / 100 \mathrm{~g}$ in the flesh. Similarly, protein and fat showed highest values in the flesh $(36.30 \pm 0.01 \mathrm{~g} / 100 \mathrm{~g}$ and $24.54 \pm 0.02 \mathrm{~g} / 100 \mathrm{~g}$, respectively) and least values in the carapace $(30.30 \pm 0.02 \mathrm{~g} / 100 \mathrm{~g}$ and $12.59 \pm 0.01 \mathrm{~g} / 100 \mathrm{~g}$, respectively) $(\mathrm{p}<0.05)$. In contrast, the flesh had the lowest contents of carbohydrate $(29.82 \pm 0.02 \mathrm{~g} / 100 \mathrm{~g})$, ash $(7.26 \pm 0.02 \mathrm{~g} / 100 \mathrm{~g})$ and crude fibre $(1.91 \pm 0.01 \mathrm{~g} / 100 \mathrm{~g})$, which showed highest amounts in the carapace $(40.10 \pm 0.10 \mathrm{~g} / 100 \mathrm{~g}, 13.17 \pm 0.02 \mathrm{~g} / 100 \mathrm{~g}$ and $3.70 \pm 0.10 \mathrm{~g} / 100 \mathrm{~g}$, respectively) $(\mathrm{p}<0.05)$.

\section{Energy value}

Figure 1 shows the energy values (mean \pm SEM Kcal $/ \mathrm{g}$ ) of the three body parts. The results indicate that the carapace had the highest energy value $(5.79 \pm 0.36 \mathrm{kcal} / \mathrm{g})$ followed by the limbs $(4.85 \pm 0.36 \mathrm{kcal} / \mathrm{g})$, while the flesh recorded the lowest energy value $(4.50 \pm 0.09 \mathrm{kcal} / \mathrm{g})$ $(p<0.05)$.

\section{Mineral composition}

Table 2 presents the mineral contents of the different body parts. All the samples showed appreciable quantities of the six minerals estimated. Sodium was the most predominant $\quad(139.25 \pm 0.36 \mathrm{mg} / 100 \mathrm{~g}$ $154.46 \pm 0.08 \mathrm{mg} / 100 \mathrm{~g}$ ) of the minerals followed by calcium $\quad(105.46 \pm 0.01 \mathrm{mg} / 100 \mathrm{~g}-143.53 \pm 0.06 \mathrm{mg} / 100 \mathrm{~g})$. The flesh recorded the highest levels of all the minerals except calcium, which occurred most in the carapace $(143.53 \pm 0.06 \mathrm{mg} / 100 \mathrm{~g})$ followed by the limbs $(140.33 \pm 0.10 \mathrm{mg} / 100 \mathrm{~g})(p<0.05)$. 


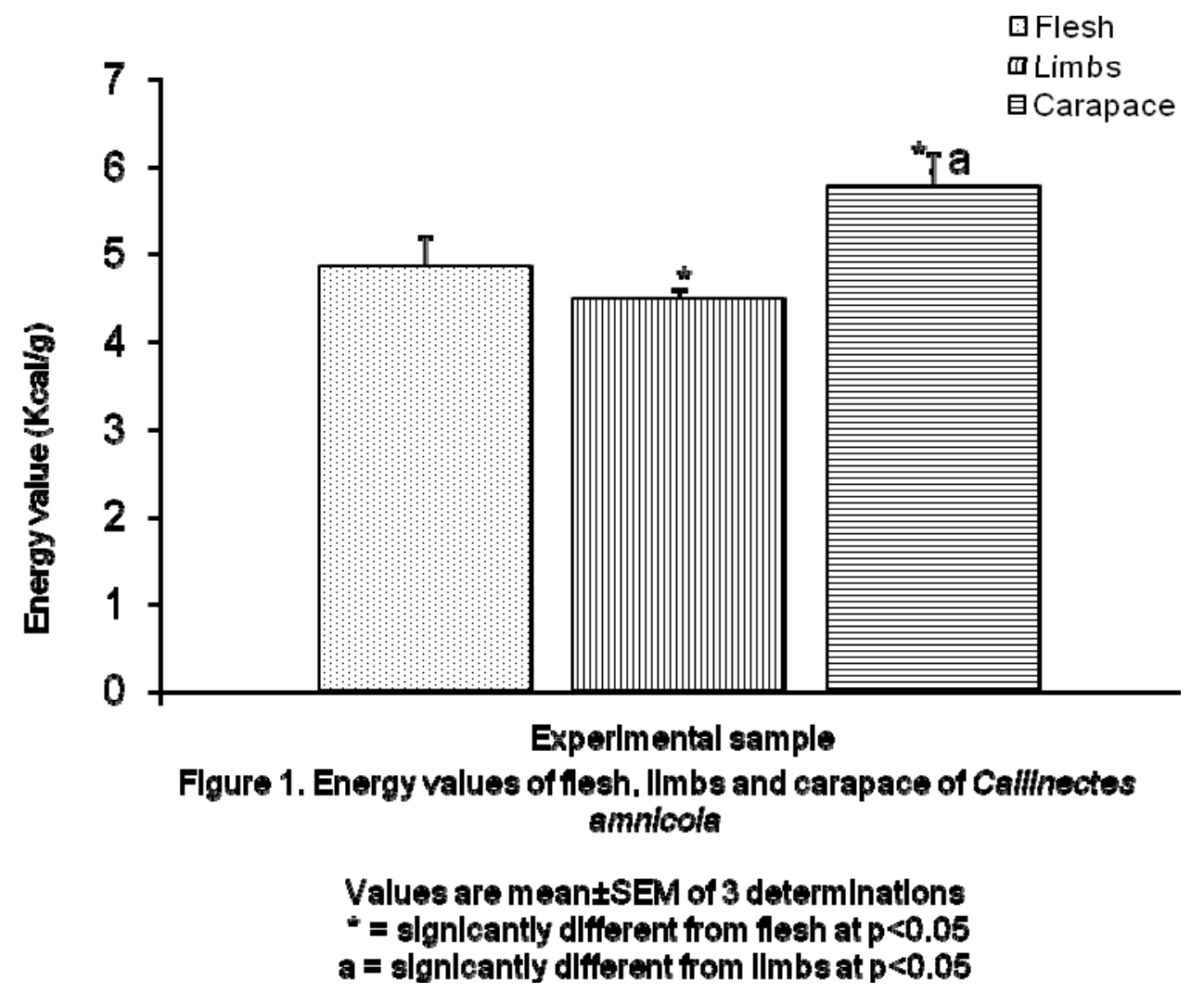

\section{DISCUSSION}

This study sought to investigate the levels of nutrients in three body parts (flesh, limbs, carapace) of Callinectes amnicola. The results showed some significant differences in the levels of nutrients across the parts analysed. Such differences across body parts have been reported in crabs and other crustaceans (Udo and Arazu, 2012; Ekpenyong et al., 2013). For the proximate constituents, moisture, protein and fat were more predominant in the flesh than in the other body parts. The high levels of moisture observed in this study are consistent with those reported by other workers for crabs of the same (Moronkola et al., 2011; Udo and Arazu, 2012) and other species (Skonberg and Perkins, 2002; Kelley et al., 2007; Kathirvel et al., 2014; Omotayo et al., 2014). These results are an indication that fresh crabs have poor keeping quality and require immediate drying or processing to enhance their storing capability.
The results of this study further reveals that the blue $c r a b$ is a rich source of protein. This is in line with several reports that crabs are high in protein and could be used to combat protein malnutrition much like the conventional animal protein sources like cattle, goat and chicken (Udo and Arazu, 2012; Omotayo et al., 2013). However, the mean crude protein contents recorded by the different body parts in this study are higher than the values (19.80\%-28.00\%) reported by Moronkola et al. (2011) for the same crab species. The observed differences in protein levels could be due to physiological, environmental or seasonal differences, which as reported by Petricorena (2014) are the usual factors that may cause variation in the chemical composition of crabs. These factors could also probably account for the observed differences in the levels of fat and other nutrients between this study and others. For instance, the body parts in this study showed higher levels of total fat than the levels reported by Moronkola et al. (2011) for $C$. 
Table 2. Mineral composition of different body parts of Callinectes amnicola ( $\mathrm{mg} / 100 \mathrm{~g}$ dry matter)

\begin{tabular}{lllllll}
\hline & Sodium & Potassium & Calcium & Magnesium & Iron & Zinc \\
\hline Flesh & $154.46 \pm 0.08$ & $27.07 \pm 0.02$ & $105.46 \pm 0.01$ & $19.68 \pm 0.13$ & $16.42 \pm 0.10$ & $4.47 \pm 0.06$ \\
& & & & & & \\
Limbs & $149.52 \pm 0.09^{*}$ & $23.59 \pm 0.07^{*}$ & $140.33 \pm 0.10^{*}$ & $14.47 \pm 0.09^{*}$ & $13.54 \pm 0.31^{*}$ & $3.74 \pm 0.13^{*}$ \\
& & & & & & \\
Carapace & $139.25 \pm 0.36^{*, \mathrm{a}}$ & $14.48 \pm 0.11^{*, \mathrm{a}}$ & $143.53 \pm 0.06^{*, \mathrm{a}}$ & $12.68 \pm 0.14^{*, \mathrm{a}}$ & $9.56 \pm 0.06^{*, \mathrm{a}}$ & $2.53 \pm 0.12^{*, \mathrm{a}}$ \\
& & & & & & \\
\hline
\end{tabular}

Values are expressed as mean \pm SEM, $n=3$.

* $=$ significantly different from flesh at $p<0.05$

$\mathrm{a}=$ significantly different from limbs at $p<0.05$

amnicola and by Udo and Arazu (2012) for C. amnicola and Uca tangeri.

The results of the present study also reveal low energy values for the different body parts of $C$. amnicola. This is consistent with the reports by other workers (Ravichandran et al., 2009) that crustaceans are generally low in energy, making them a very healthy choice of food. The carapace had a significantly higher energy value than the other two body parts studied. A similar observation was reported by Ekpenyong et al. (2013) in their studies on another shellfish (prawn: Macrobrachium macrobranchion), which they attributed to the presence of chitin a linear polysaccharide in the exoskeleton. High content of chitin has been reported in crabs and other seafoods (Kurita, 2006; Ifuku et al., 2009). The same must have probably accounted for the higher energy value in the carapace observed in this study.

This study also shows that the different body parts of C. amnicola constitute a rich source of important macroand micro-mineral elements. This is in line with the findings of other studies (Gokoglu and Yerlikaya, 2003; Naczk et al., 2004; Soundarapandian et al., 2014) that crab meat is an excellent source of minerals, particularly calcium, potassium, iron, zinc and phosphorus. In this study, sodium and calcium showed maximum levels in all the body parts studied. Soundarapandium et al. (2014) had made a similar observation in their studies on another edible crab species (Podophthalmus vigil Fabricius), irrespective of sex differences. Nevertheless, some variations do exist between the mineral contents recorded in this study and those of other studies (Udo and Arazu, 2012; Omotayo et al., 2013). It has been reported that variations in the mineral composition of marine foods are closely related to seasonal and physiological differences, area of catch, food source, and other environmental conditions (Soundarapandian et al., 2014). It is possible that these factors were also responsible for the observed differences in mineral composition between the present study and others.

This study reveals that the different body parts of Callinectes amnicola are rich in nutrients. In order to fully utilize the nutrients, it is suggested that the carapace and other hard body parts of C. amnicola should be blended together into a nutraceutical that could have a wide range of applications.

\section{REFERENCES}

Adeyeye EI (2002). Determination of the chemical composition of the nutritionally valuable parts of male and female common West African fresh water crab Sudananautes africanus africanus. Int. J. Fd. Sc. Nutr. 53 (3): $189-196$

Adeyeye El (1996). Waste yield, proximate and mineral compositions of three types of land snails found in Nigeria. Int. J. Food Sci. Nutr. 47: $11-116$.

AOAC (2005). Association of Official Analytical Chemists. Official methods of analysis (18 ${ }^{\text {th }}$ ed.). Arlington, V. A., USA.

Appel IJ, Brands MW, Daniels SR, Karanja PJ, Elmer S, Sacks EM (2006). Dietary approaches to prevent and treat hypertension: a scientific statement from the American Heart Association. Hypertension 47 (2): $296-308$.

Atwater WO, Bryant AP (1990). The availability and fuel value of food materials. Agriculture Experiment Station $12^{\text {th }}$ Annual Report. US Government Printing Office, Washington, DC, pp73 - 110.

Defilippis AP, Blaha MJ, Jacobson TA (2010). Omega-3 fatty acids for cardiovascular disease prevention. Curr. Treat. Options. Cardiovasc. Med. 12 (4): 365 - 380.

Dias MG, Sanchez MV, Bartolo H, Oliveira L (2003). Vitamin content of fish and fish products consumed in Portugal. Electron. J. Environ. Agric. Food Chem. 2(4): 510-513

Ekpenyong E, Williams IO, Asakpa UU (2013). Variation in the proximate, energy and mineral compositions of different body parts of Macrobrachium macrobranchion (prawn). J. Food Res. 2 (2): 150 $-156$.

Elegbede IO, Fashina-Bombata HA (2013). Proximate and mineral compositions of common crab species (Callinectes pallidus and Cardisoma armatum of Badagry creek, Nigeria. Poult. Fish Wildl. Sci. 2: $2-5$.

Gokoglu N, Yerlikaya P (2003). Determination of proximate composition and mineral contents of blue crab (Callinectes sapidus) and swim crab (Portuns pelagicus) caught off the Gulf of Antalya. Food Chem. 80: 495 - 498 .

Holland B, Brown J, Bush DH (1993). Fish and fish products. In: The fifth supplement of McCance and Widdowson's The composition of foods. Royal Society of Chemistry, Cambridge/London

Ifuku S, Nogi M, Abe K, Yoshioka M, Morimoto M, Saimoto H, Yano H (2009). Preparation of chitin nanofibers with a uniform width as $\alpha$ chitin from crab shells. Biomacromolecules 10: $1584-1588$. 
IOM (2006). Institute of Medicine. Seafood choices: Balancing benefits and risks. National Academies Press, Washington, D. C. 20055 , USA.

Kathirvel K, Eswar A, Manikandarajan T, Ramamoorthy K, Sankar G, Anbarasu R (2014). Proximate composition, amino acid, fatty acid and mineral analysis of box crab, Calappa lophus (Herbst, 1872) from Parangipettai, Southeast Coast of India. IOSR-JESTFT. 8 (5): $50-57$.

Kelley EF, Ozogul Y, Ogungolu Al (2007). Comparison of fatty acid and composition of the body and claw of male and female blue crabs (Callinectes sapidus) from different regions of the Mediterranean. Int. J. Food Sci. Nutr. 59 (7-8): $573-587$.

Kurita K (2006). Chitin and Chitosan: Functional biopolymers from marine crustaceans. Marine Biotechnol. 8: $203-226$.

Maziya-Dixon B, Akinyele IO, Oguntona EB, Nokoe S, Sanusi RA, Harris E (2004). Nigerian Food Consumption and Nutrition Survey 2001-2003 (Summary). IITA, Ibadan - Nigeria.

Moronkola BA, Olowu RA, Tovide OO, Ayejuyo OO (2011). Determination of proximate and mineral contents of crab (Callinectes amnicola) living on the shore of Ojo River, Lagos, Nigeria. Sci. Revs. Chem. Commun. 1 (1): $1-6$.

Naczk M, Williams J, Brennam K, Liyanapathirana C, Shahidi F (2004). Compositional characteristics of green crab (Carcinus maenas). Food Chem. 88 (3): 429 - 434.

Nodari S, Triggiani M, Campia U, Manerba A, Milesi G, Bruno M, Cesana BM, Gheorghiade M, Cas LD (2011). Effects of n-3 polyunsaturated fatty acids on left ventricular function and functional capacity in patients with dilated cardiomyopathy. J. Am. Coll. Cardiol. 57 (7): $870-879$.

Omotayo F, Adesola MF, Abayomi OJ (2014). Proximate composition and mineral content of the Land Crab Sudanonautes africanus. J. Sci. Res. Reports. 3 (2): $349-355$.

Omotayo F, Abayomi OJ, Adesola MF, Olawale OA (2013). Quality analysis of fresh water crab Cardisoma Armatum and Marine blue crab Callinectes amnicola collected from Yaba Lagos, Nigeria. Nat. Sci. 11 (8): $22-29$

Petricorena ZC (2014). Chemical composition of fish and fishery products. Handbook of Food Chemistry. Cheung, P.C.K. and Mehta, B.M. (eds.). Springer Berlin Heidelberg, pp1 - 28.
Ravichandran S, RameshKumar G, Prince AR (2009). Biochemical composition of shell and flesh of the Indian white shrimp Penaeus indicus (H. Milne Edwards 1837). American-Eurasian J. Sci. Res. 4 (3): $191-194$.

Roth EM, Harris WS (2010). Fish oil for primary and secondary prevention of coronary heart disease. Curr. Atheroscler. Rep. 12: 66 -72 .

Skonberg DI, Perkins BL (2002). Nutrient composition of green crab (Carcinus maenus) legmeat and clawmeat. Food Chem. 72: 401 404

Soundarapandian P, Varadharajan D, Ravichandran S (2014). Mineral composition of edible crab Podophthalmus vigil Fabricius (Crustacea: Decapoda). Arthropods. 3 (1): $20-26$.

Ubesie AC, Ibeziakor NS (2012). High burden of protein-energy malnutrition in Nigeria: Beyond the health care setting. Ann. Med. Health Sci. Res. 1: $66-69$

Udo JP, Arazu VN (2012). The proximate and mineral composition of two edible crabs Callinectes amnicola and Uca tangeri (Crustacea Decapoda) of the Cross River, Nigeria. Pak. J. Nutr. 11 (1): $78-82$.

Wilk JB, Tsa MY, Hanson NQ, Gaziano JM, Djousse L (2012). Plasma and dietary omega-3 fatty acids, fish intake, and heart failure risk in the Physicians' Health Study. Am. J. Clin. Nutr. 96 (4): 882 - 888. 